\title{
Influence of Resting from Tapping on the Survival and Frankincense Yield of Boswellia Papyrifera Trees in Ethiopia
} \author{
Akalu $^{3}$ \\ ${ }^{1}$ Bahir Dar Environment and Forest Research Center, Ethiopia \\ ${ }^{2}$ Ethiopian environment and Forest Research Institute, Ethiopia \\ ${ }^{3}$ Gondar Agricultural Research center, Ethiopia
}

Ambachew Getnet Asfaw ${ }^{1 *}$, Tatek Dejene², Kibruyesfa Sisay ${ }^{2}$, Hadera Kahasay ${ }^{3}$, Elliyas Cherent ${ }^{3}$, and Bihonegne

Submission: September 23, 2019; Published: November 01, 2019

*Corresponding author: Ambachew Getnet Asfaw, Bahir Dar Environment and forest research center, P. O. Box: 2128, Bahir Dar, Ethiopia

\begin{abstract}
Introduction

About half of the total landmass in Ethiopia is arid to be semiarid [1], with no marginal agricultural potentials. Nevertheless, several indigenous trees and shrubs in these vast arid and semiarid lowlands of the country have been known to yield economically valuable products since several millennia. Ethiopian natural vegetation resources include several species of potential importance. For instance, the AcaciaCommiphera woodlands in the dry lands of the country that are dominated by Acacia, Boswellia, and Commiphera species are well known for their economically valuable products, largely oleo-gum resins such as gum arabic, frankincense, myrrh, and karaya [2-5].
\end{abstract}

The potential area covered by natural gum and resin-bearing species is believed to be very high in Ethiopia. Preliminary mapping and assessments show that the resource is found in eight regions covering an area of about 2.9 million ha. [6]. Tigray and Amhara National Regional State (ANRS) constitute the leading natural gum and resin bearing forest resource base, $32.9 \%$ and $23.8 \%$ respectively. Vast areas of land, ca. $51 \%$, in Ethiopia are arid to semiarid (Le Houérou, 1996; Tamerie Hawando, 1997) [1] with marginal or no agricultural potentials. Including the dry sub-humid area, the total dry landmass of the country amounts $860,000 \mathrm{~km} 2$ (ca. 71\%) (Tamerie Hawando, 1997). Nevertheless, many of the indigenous trees and shrubs in these vast arid and semi-arid lowlands hold known or potential promise for the production of economically valuable products, principally oleo gum resins such as gum acacia (gum arabic and gum talha), frankincense, myrrh, hinna, and gum karaya (Stiles, 1988; EFAP, 1993; Kuchar, 1995; FAO, 1995; Mulugeta Lemenih et al. in press).

Boswellia papyrifera is an indigenous gum producing multipurpose perennial tree species that grow in drier parts of Africa from Nigeria in the west to Eritrea and Ethiopia in the east. In ANRS, the woodlands dominated by B.papyrifera stands are identified in nine zones covering 34 woredas and 151 PAS. It is found abundantly in Metema, Quara and Armachiho woredas of North Gondar Zone (NGZ). Boswellia has an immense ecological and economic significance [7]. It is found to be highly suitable for future reforestation establishments or restoration efforts in moisture deficit arid and semi-arid areas [8]. This species produces frankincense, an oleo-gum resin valued for its industrial, folk medicine, cultural and religious uses [6]. It has wide demand in domestic and international markets.

At present, Boswellia papyrifera is threatened as the result of several interrelated factors. Increasing population pressure has resulted in the conversion of woodlands to agricultural land while unregulated grazing by which young seedlings are either eaten or trampled by livestock, is hindering the natural regeneration. Another factor causing the decline of Boswellia papyrifera is suggested that the exploitation system. Trees are tapped every year in the dry season. The frankincense tapers are paid based on the amount of gum collected. This easily can lead to over tapping. Intensive tapping is thought to have resulted in the death of many trees, especially during the period of drought. Furthermore, there are indications that over-tapping may lead to poor flower and seed production and hence poor regeneration. All these factors deceasing Boswellia stand at alarming rate in the study area. Therefore, proper planning, for the development, conservation and sustainable utilization of this potential resource is urgently required. Therefore, the main objective of this study was examining the influence of resting on the survival and frankincense yield of matured Boswellia papyrifera trees. More specifically to determine the annual yield of frankincense that can be harvested from a tree per year and recommend the best season for high yielding of frankincense.

Keywords: Boswellia papyrifera; Development; Conservation; Sustainable utilization; Agricultural households 


\section{Materials and Methods}

\section{Site description}

Metema woreda is located about $900 \mathrm{~km}$ northwest of Addis Ababa and about $180 \mathrm{~km}$ west of Gondar town. Metema woreda has an international boundary of more than $60 \mathrm{~km}$ long distance between Ethiopia and Sudan. It is found North of Quarra and Alefa, west of Chilga south of Tach Armachoho woredas and east of Sudan border. It is one of the 18 woreda in North Gondar Zone. According to the woreda Plan for 2004, there are 15,675 rural Agricultural households (excluding the newly resettled households) and about 4,991 urban households. According to this estimate, the total population of the woreda is 91,216 people. Out of the total, 3918 are rural and 1497 are urban women households. The original residents of the area are Gumuz. Until recently, they practice slash and burn and hunting wild animals. They produce sorghum as the staple crop and remain to be the major food crop in the area. Since the settlement programmes of the last and current governments, the area is populated, and the natives became small in number. They are concentrated in few areas and live close to each other. They are found in only three PAs (Kumer Aftit, Tumet and Shinfa). The total number of the indigenous people would be around 500 households. Hence much of the area is recently settled by newcomers from the highlands. During the group's visit to the woreda, it was known that 11,000 settlers would be received during 2004/05. About 3,000 settlers were received when the team was in the woreda.

The altitude of Metema ranges from as low as 550 to $1608 \mathrm{~m}$. a.s.l while the minimum annual temperature ranged between $22^{\circ} \mathrm{C}$ and $28^{\circ} \mathrm{C}$. Daily temperature becomes very high during the months of March to May, where it may get to as high as $43^{\circ} \mathrm{C}$. Nearly all of the land in the woreda is in the lowlands except some mountain tops which fall outside. At the time of the visit, the temperature was around $36^{\circ} \mathrm{C}$. Metema is one of the woreda in the country where the climate is harsh, and government allows a Result
$30 \%$ hardship allowance. According to the available digital data, the mean annual rainfall for the area ranges from about 850 to around $1100 \mathrm{~mm}$. These values are not in agreement with what has been reported by the OoA. Based on this digital data, about $90 \%$ of the woreda receives mean annual rainfall of between 850 and $1000 \mathrm{~mm}$. Metema has a unimodal rainfall. The rainy months extend from June until the end of September. However, most of the rainfall is received during the months of July and August. Rainfall during these months is erratic, combined with the poor workability of most of the soils, farm operations are also affected. The soils in the area are predominantly black and some are soils with vertic properties. Due to the season, soils in most of the areas visited were observed with excessive cracks, which could be as deep as $0.75 \mathrm{~m}$ in some places.

\section{Research design}

Homogeneous site was delineated for the selection of trees. Trees which have similar tapping history and be tapped one year before the experiment started were selected. Within each area, trees having diameters of $10-20$ and $>20 \mathrm{~cm}$ were randomly selected. For each diameter class, twenty-five trees taken and labeled. These trees then allocated to five different tapping resting categories ( $n=5$ per tapping resting categories) i.e. tapped in each years, tapped one year and rest one year, tapped for two years and rest one year, tapped for three years and rest one year and the remaining are left without being taped. Following the traditional/ local practices each category was taped according to the time allocated for each trial i.e.1, 2, 3 and 4 years. Each sampled tree was tapped eleven times every year (T1-T11). The gum obtained from each tree then collected and compared to see the impact of resting on the yield of gum from the trees. Analysis of variance was performed to assess variations among Treatments. $L s d$ mean separation method was employed if significant differences are found among experimental variables. And the result is presented in means and graph forms

\section{High frankincense yielding season}

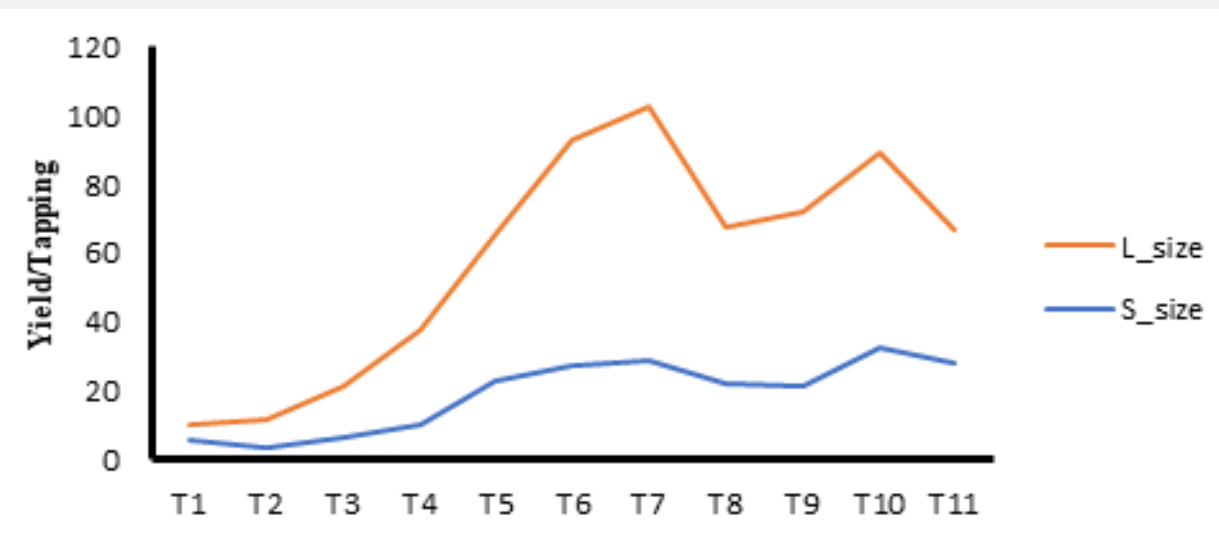

Figure 1: Frankincense yield variation according to local tapping practice period in the lowland of Metema, Ethiopia. 


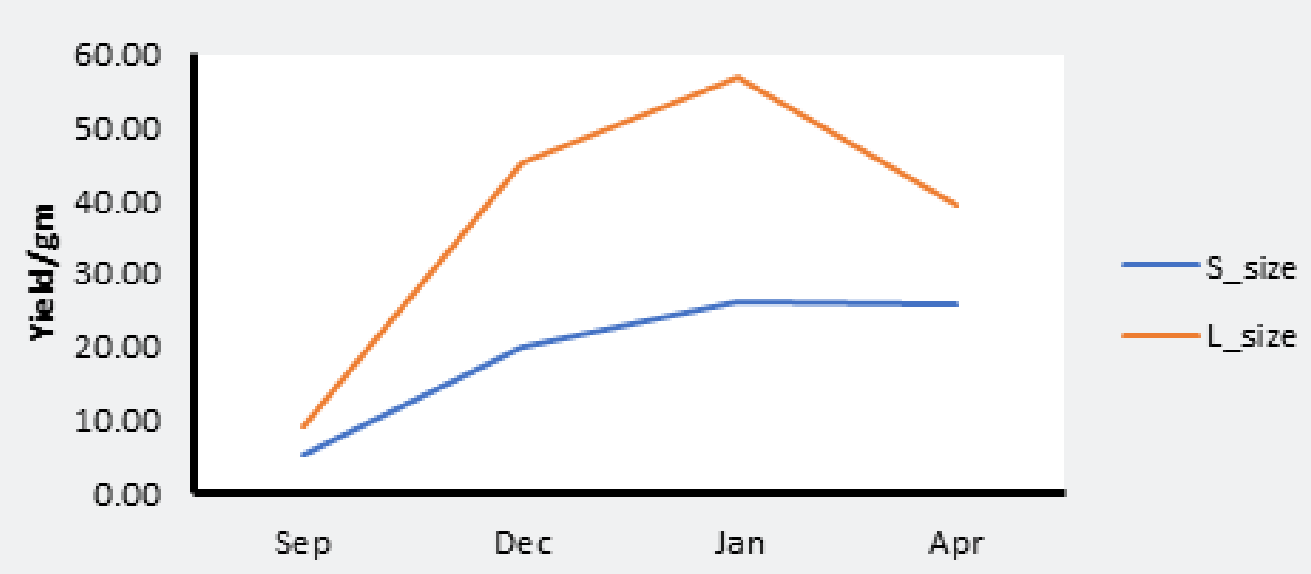

Figure 2: Frankincense yield variation in months' through the year in the lowland of Metema, Ethiopia

From the frankincense yield collected from tapping of matured Boswellia papyrifera tress, it has been possible to identify the high yielding time from the trees. Since frankincense production is the response of physiological responses of the tress to stress, it is important to identify the best time for the trees to response actively in order to maximize frankincense yield from tapping of the trees. Accordingly, this study identified that the trees has been more responsive to tapping when they tapped from tapping period of four) (Figure 1) up to ten according to the local taping practice of the farmers in the study area. Beginning December to the mid of April were the peak period to tape the high yield from the matured Boswellia papyrifera trees (Figure 2).
At this time, it has been possible to collect the maximum yield from the trees. Thus, this indicated that trees have to be tapped effectively at this time in order to collect maximum yield of frankincense from the trees in the study area

\section{Survival of tapped Boswellia papyrifera}

Survival of trees tapped each year without resting

The result indicated that as the trees are tapped continuously without resting will have negative effect on the survival of the tapped trees. Therefore, it is easily understood that resting of Boswellia trees is a must in order to protect the trees from death (Table 1).

Table 1: Survival of trees tapped without resting in the lowland of Metema, Ethiopia.

\begin{tabular}{|c|c|c|c|}
\hline \multirow{2}{*}{ Treatments } & \multicolumn{3}{|c}{ Survival Percentage } \\
\cline { 2 - 4 } & Year 1 & Year 2 & Year 3 \\
\hline Small Sized trees & 100 & 100 & 40 \\
\hline Large Sized trees & 100 & 100 & 20 \\
\hline
\end{tabular}

\section{Survival of trees tapped one year with one year resting}

Of tapped trees, ten of them from small five trees and large five trees sized trees has been assigned to be tapped for one year and got rest for one year and then tapped to see the effect of one year tapping and one year resting on the survival of matured Boswel- lia papyrifera tress in the study area. The results of this tapping schedule indicated that tapping of trees for one year and provide rest one year regularly after one tapping year will provide better survival or provide less mortality to the tapped tress in the study area (Table 2)..

Table 2: Survival of trees tapped one year with one year resting in the lowland of Metema, Ethiopia.

\begin{tabular}{|c|c|c|c|c|}
\hline \multirow{2}{*}{ Treatments } & \multicolumn{4}{|c|}{ Survival Percentage } \\
\cline { 2 - 5 } & Year 1 & Year 2 & Year 3 & Year 4 \\
\hline Small Sized trees & 100 & 100 & 100 & 80 \\
\hline Large Sized trees & 100 & 100 & 100 & 100 \\
\hline
\end{tabular}

Survival of trees tapped two year with one year resting

Table 3: Survival of trees tapped two year with one year resting in the lowland of Metema, Ethiopia.

\begin{tabular}{|c|c|c|c|c|}
\hline \multirow{2}{*}{ Treatments } & \multicolumn{4}{|c|}{ Survival Percentage } \\
\cline { 2 - 5 } & Year 1 & Year 2 & Year 3 & 60 \\
\hline Small Sized trees & 100 & 100 & 80 & 20 \\
\hline Large Sized trees & 100 & 100 & 80 & 60 \\
\hline
\end{tabular}


Of tapped trees, ten of them from small (5trees) and large (5 trees) sized trees has been assigned to be tapped for two years and got rest for one year and then tapped to see the effect on the survival of matured Boswellia papyrifera tress in the study area. The results of this tapping schedule indicated that tapping of trees for two continuous years and provide rest for one year regularly will provide is high mortality of tapped trees as compared to those trees tapped one year and gets one-year rest (Table 3).

\section{Trees tapped three years with one year resting}

Of tapped trees, ten of them from small (5trees) and large (5 trees) sized trees has been assigned to be tapped three years continuously and left for one year resting. The result of this tapping category indicated that there a high mortality to the tapped trees next to the continuously tapped trees category in the study area (Table 4).

Table 4: Survival of trees tapped three years with one year resting in the lowland of Metema, Ethiopia.

\begin{tabular}{|c|c|c|c|c|}
\hline \multirow{2}{*}{ Treatments } & \multicolumn{4}{|c|}{ Survival Percentage } \\
\cline { 2 - 5 } & Year 1 & Year 2 & Year 3 & Year 4 \\
\hline Small Sized trees & 100 & 100 & 60 & 20 \\
\hline Large Sized trees & 100 & 100 & 80 & 40 \\
\hline
\end{tabular}

\section{Frankincense yield}

The result indicated that there were significant differences among those treatments (Large trees one year tapped one-year rest, large trees three years tapped and one-year rest, and Small trees three years tapped and one-year rest). From trees having large diameter one year tapped and one-year rest obtained high mean yield followed by large trees three years tapped and oneyear rest. But trees having small diameter and every year tapped have lower yield followed by trees Small trees Two years tapped and one-year rest and large trees every year tapped (Table 5).

Table 5: Effect of resting on frankincense yield in the lowland of Metema, Ethiopia.

\begin{tabular}{|c|c|}
\hline Treatment & Mean Yield \\
\hline Large trees one year tapped one-year rest & $535.30^{\mathrm{a}}$ \\
\hline Large trees three years tapped and one-year rest & $404.82^{b}$ \\
\hline Large trees two years tapped and one-year rest & $307.09^{c}$ \\
\hline Small trees one year tapped and one-year rest & $282.50^{c}$ \\
\hline Small trees three years tapped and one-year rest & $164.82^{\mathrm{d}}$ \\
\hline Large trees every year tapped & $151.86^{\text {de }}$ \\
\hline Small trees Two years tapped and one-year rest & $147.97^{\text {de }}$ \\
\hline Small trees every year Tapped & $77.60^{\mathrm{e}}$ \\
\hline
\end{tabular}

\section{Discussion}

Based on the result, trees that has been collected from tapping of matured small and large sized Boswellia papyrifera trees, the frankincense production potential of the study area is found to be 77.6 to $535.3 \mathrm{gm} /$ tree/year respectively. This figure ranges from 77.6 to $282.5 \mathrm{gm} /$ tree/year and 151.86 to $535 \mathrm{gm} /$ tree/ year for small and large sized trees respectively. Different scholars reported that on their study different frankincense yield for instance Tadesse et al. (2004) reported a range of 6.7-451.4gm/ tree/year, Abeje \& Asmamaw [9] reported a frankincense yield of 207-352gm/tree/year and Girmay [6] reported 500gm/tree/ year of frankincense to be collected from Boswellia papyrifera tree under normal frankincense production techniques. A similar study on the yield potential of Boswellia papyrifera in the Metema area (Wubalem et al. 2004) Asmamaw \& Abeje [9], revealed the potential of $67.5 \mathrm{~kg}$ of frankincense production from a hectare of Boswellia woodland, and; Mesfin et al. [10] also reported frankincense production per hectare from open and closed area in Tigray to be $254.18 \mathrm{~kg}$ and $169.08 \mathrm{~kg}$ respectively. This figure indicated that frankincense yield production is highly influenced by the tree size of the stand thus the higher yield has been obtained from the larger sized matured Boswellia papyrifera trees as compared to the small sized matured tress in the study area. Generally, from the stand analysis of the Boswellia dominated woodland of Metema woreda, in a hector of land it is possible to find cal. 250 to 300 matured Boswellia papyrifera tress. Therefore, it is likely to harvest frankincense yield on the average of cal. $45.1 \mathrm{~kg} / \mathrm{ha} /$ year in the range between cal. 19.4 to $70.6 \mathrm{~kg} / \mathrm{ha} /$ year from small sized matured trees and average yield of cal. $85.89 \mathrm{~kg} / \mathrm{ha} /$ year in the range between cal. 37.96 to $133.82 \mathrm{~kg} /$ tree/year from large sized trees depending on the site condition and density of the tree in the study area.

\section{Conclusion}

From the beginning December to the mid of April were the peak period to tape the high yield from the matured Boswellia papyrifera trees. From this study tapping period of four (T4) up to ten (T10) gave more yield than other period. It also indicated that tapping ( $\mathrm{T}$ 7) highest yield approximately $0.1 \mathrm{~kg} /$ tree $/ \mathrm{yr}$ 
and $0.032 \mathrm{~kg} /$ tree $/ \mathrm{yr}$ for large and small matured Boswellia trees respectively. Trees tapped three years and one-year rest indicated that there is a high mortality for both diameter classes in the study area. Trees for one year tapped and one-year rests regularly had shown better survival or provide less mortality. Trees having large diameter one year tapped and one-year rest obtained high mean yield of $0.535 \mathrm{~kg} /$ tree/year and followed $0.404 \mathrm{~kg} /$ tree $/$ year for large trees three years tapped and one-year rest. Trees having small diameter and every year tapped have lower yield followed by trees Small trees Two years tapped and one-year rest and large trees every year tapped. Since tapped trees continuously without resting had negative impact on the survival of trees therefore resting period for Boswellia papyrifera is a must. Tapping of one year and allowing one year resting have higher survival and frankincense yield therefore resting period should be done accordingly. A scientific guideline for frankincense production and on different tapping techniques shall be developed and implemented. Moreover, further training shall be given for the local community and gum and resin producing organizations.

\section{Acknowledgement}

We would like to acknowledge Amhara Regional Agricultural Research Institute (ARARI) and Gondar Agricultural Research Center for their financial and material support.

\section{References}

1. NCSS (National Conservation Strategy Secretariat) (1993) National Conservation Strategy: National Policy on the Resources Base, its Utilization and Planning for Sustainability. NCSS, Addis Ababa, Ethiopia.
2. Eshet A (2002) Regeneration status, soil seed banks and socioeconomic importance of Boswellia papyrifera in two woredas of northern Gondar zone, Ethiopia. MSc thesis, Swedish university of agricultural sciences, Sweden.

3. Lemeneh M, Teketay D (2003) Frankincense and myrrh resources of Ethiopia: I Distribution, production, opportunities for dry land development and research needs. Sinet: Ethiop J Sci 26(1): 63-72.

4. Tilahun G (1997) Boswellia papyrifera (Del.) Hochst. From Western Tigray: opportunities, constraints and seed germination responses. MSc thesis, Report No. 1996: 12. Swedish University of Agricultural Sciences, Faculty of Forestry, Sweden, p. 58.

5. Tadesse W, Feleke S, Eshete T (2004) Comparative study of traditional and new tapping method on frankincense yield of Boswellia papyrifera. Ethiopian Journal of Natural Resources 6: 287-299.

6. Fitwi G (2000) The status of gum Arabic and resins in Ethiopia. Report of the Meeting of the Network for Natural Gum and Resins in Africa (NGARA) 29 $9^{\text {th }}-31^{\text {st }}$ May, Nairobi, Kenya, pp. 14-22.

7. Tesemma AB, Ann B, Bo T (1993) Useful trees and shrubs for Ethiopia. Identification, Propagation and Management for Agricultural and Pastoral Communities Regional Soil Conservation Unit, SIDA, Nairobi.

8. Gebrehiwot K, Muys B, Haile M, Mitloehner R (2005) The use of plant water relations to Characterize tree species and sites in the drylands of northern Ethiopia. Journal of Arid Environments 60(4): 581-592.

9. Alem A, Eshete A (2007) The effect of tapping intensity and tree diameter (size) on Frankincense yield of Boswellia papyrifera (Del) Hochst: a key dry land species in Northern Ethiopia.

10. Tilahun M, Olschewski R, Kleinn C, Gebrehiwot K (2007) Economic analysis of closing degraded Boswellia papyrifera dry forest from human interventions - a study from Tigray, Northern Ethiopia. Forest Policy and Economics 9(8): 996-1005.

\section{Your next submission with Juniper Publishers} will reach you the below assets

- Quality Editorial service

- Swift Peer Review

- Reprints availability

- E-prints Service

- Manuscript Podcast for convenient understanding

- Global attainment for your research

- Manuscript accessibility in different formats ( Pdf, E-pub, Full Text, Audio)

- Unceasing customer service

Track the below URL for one-step submission https://juniperpublishers.com/online-submission.php 